\title{
How Student Entrepreneurs Develop Their Social Network Over Time During the Process of Starting a Company
}

\author{
Martin Haring \\ Correspondence: Martin Haring, faculty of business and economics of the university of applied sciences Amsterdam, \\ the Netherlands. E-mail: m.haring@hva.nl
}

Received: February 5, 2018

doi:10.11114/bms.v4i1.2979

\author{
Accepted: February 25, 2018 \\ Online Published: February 27, 2018 \\ URL: https://doi.org/10.11114/bms.v4i1.2979
}

\begin{abstract}
Recent studies have focused on which networks would help entrepreneurs to become successful and what would be the best mix of strong ties and weak ties to build an organization upon. With this longitudinal research we add insights into the process of network development on an individual level and complement earlier research on this topic.

This article explores the development of strong and weak ties in the social network of student entrepreneurs and the role five mechanisms of social networking play in the process of opportunity recognition, resource mobilization and gaining legitimacy, through a longitudinal case study among 17 student start-ups in the period 2009-2013.

All student entrepreneurs started their businesses in the last two years of their bachelor education, part of a venture creation program. They were interviewed directly after they had started their businesses, and their activities were monitored while they were developing their businesses and networks over a period of three years.

This study adds to the current social network literature by analyzing how student entrepreneurs use social networking while being involved in the entrepreneurial process of starting a business and especially make use of the advantages of being a student, i.e. being part of the network and having access to the resources of the university. Successful student entrepreneurs distinguish themselves of the rest by keeping on adding valuable connections to their network, having no fear in asking for help and profiting of the goodwill in the business world towards student entrepreneurs.
\end{abstract}

This article can be of use for both academics and practitioners.

Keywords: social networks, student entrepreneurs, university, network development, mechanisms of networking, entrepreneurial processes, venture creation programs

\section{Introduction}

While starting your own business has become more and more popular by students at bachelor or master level, and universities have developed venture creation programs to guide students through the process of starting their own business (Lackeus M. \& Williams Middleton K.,2015; Hulsink \& Koek, 2014), student entrepreneurs have to start with activating their own social network in these cases, and build the social capital of the firm from scratch, often with the help of the network of the university, family and friends (Rasmussen et al., 2015). For students in general, research suggests that good contacts (i.e., a high level of social capital) are helpful in obtaining jobs (Burt, 1997), getting promoted (Podolny \& Baron, 1997), and having a successful career (Seibert et al., 2001). Students who want to start their own business have to realize that connections to others can be crucial for the success of their endeavor to create a sustainable company. How student entrepreneurs make use of their social network and how they develop it over time in favor of their company is still underexplored (Lackeus M. and Williams Middleton K., 2015; Lee \& Jones, 2008). This article aims to contribute to this gap in the literature about student entrepreneurship and social networks by making the student company started during a venture creation program and continued afterwards the unit of analysis.

Most studies about entrepreneurial networks rely on cross-sectional data and do not deal with the how and why issues of the development of a network (Stuart and Sorenson, 2007;Stam, et al., 2014; Engel et al., 2017; Lans et al., 2015; Lamine et al., 2015). These studies generate static information, about something that is, in fact, a highly dynamic process (Newbert et al., 2013). In the early stage of venture development three processes are defined that are of great importance: The discovery of opportunities, the acquiring of resources and the obtaining of legitimacy (Elfring \& Hulsink, 2003). During these processes entrepreneurs make use of their family, friends and business contacts to reach 
their goals (Newbert et al. 2013). These so called strong and weak ties play different roles in these processes (Burt, 2000). The mechanisms involved in these processes are also important for the answer to the question how networks develop over time. In 2007 Stuart and Sorensen found (based on an extensive literature research) five essential mechanisms that influence social and economic outcomes of interest: information access, brokerage, status, embeddedness and sanctions. Our proposed conceptual model (figure 1) accentuates how student entrepreneurs use these mechanisms in order to discover opportunities, get access to new resources and gain legitimacy by using strong ties and adding weak ties to their social network.

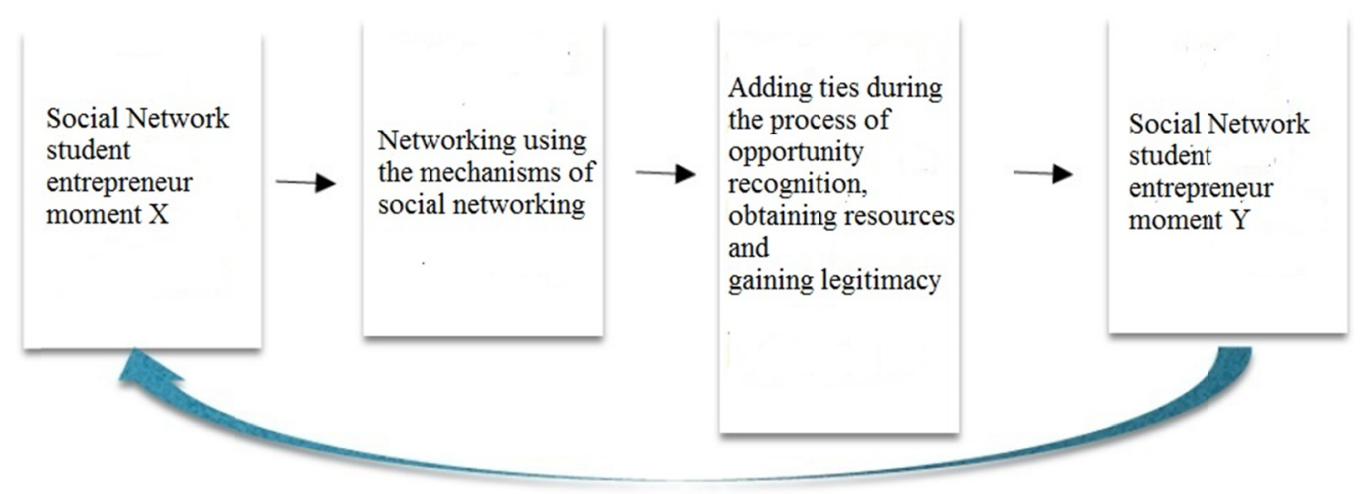

Figure 1. Conceptual model of the networking process student entrepreneurs over the years

There are three aspects to the proposed model. First of all we focus on the network of the entrepreneurs under scrutiny. We deal in this case with student entrepreneurs (aged 20-25) with a personal network that needs to be developed and in most cases consists of strong ties of family and friends. This social network needs to be activated and new social relationships need to be created (Elfring and Hulsink, 2007; Bruderl and Preisendorfer, 1998; Sarasvathy, 2001) in order to link to customers, investors, suppliers, prospects or representatives of the media, for example. We therefore define the network in this case as: the main business relationships with respect to legitimacy, sales, supply, outsourcing and cooperation (Schutjens and Stam, 2003). We map this network at the beginning of our research and keep track of it during the period we follow the student entrepreneurs.

Secondly we monitor how the network of the student entrepreneurs develops by using the mechanisms of information access and brokerage in the opportunity recognition phase and later on the mechanisms of status, embeddedness and sanctions in the resource mobilization phase to actually build a business and gaining legitimacy (According to Stuart \& Sorensen, 2007, the most prominently used mechanisms in these phases). We especially monitor the steps students take to reach out to the resource providers they are searching for and the role of the university in these cases. How does it help students to be part of the environment of the university in the case of developing their business?

Thirdly we want to find out what ties they added (or deleted) during the process of developing their business, how they (eventually) were introduced to these contacts and what resources (clients, money, expertise,...) these contacts brought to the company. We repeat this exercise every year during a period of three years. By doing so we want to answer the research question: How do student entrepreneurs gain initial entry to established networks by using social mechanisms that play a role in different stages of the entrepreneurial process, and how do they develop their network over time by using strong and weak ties?

In order to gain insights into the way student entrepreneurs develop their network we have set up a qualitative inquiry. As part of this inquiry we followed 17 student start-ups and the evolution of their network over a period of three years. The student start-ups we followed were all service related businesses and were started during a venture creation program, by bachelor students in their third or fourth year. These cases provided empirical material from which we have developed a number of propositions concerning the role mechanisms of social networking play in getting access to new information, clients and other resources to develop a new company. We will answer the research question and also try to find out if there are certain advantages or disadvantages to be a student while actually starting a company.

This article is structured as follows. In section 2, we present current network approaches and former research on start-up networks. On the basis of this literature expectations about the development of the network of the nascent entrepreneurs are formulated that are tested empirically. Section 3 focuses on the context and methodology. Section 4 is about the cases and the dataset, we present 17 cases of student entrepreneurs who continued their businesses after their graduation. All the start-ups are Dutch companies. These cases provide empirical material from which a number of propositions are 
developed concerning the way student entrepreneurs develop and make use of their social network (section 5). Finally we will draw our conclusions and give suggestions for further research.

\section{Developing a Social Network}

The presupposition of this paper is that student entrepreneurs have a rudimentary developed social network consisting of family and friends and a single business relation obtained by an internship or a side job. So while there is a great amount of uncertainty, when starting a business, it is important for the student entrepreneur to lean in the beginning on close relations like family and friends, the so-called 'strong ties' (Hite and Hesterley, 2001). People to whom somebody is emotionally attached tend to provide access to their resources often below market rates (Witt, 2004). For this reason, evidence suggests that nascent entrepreneurs will seek out individuals with whom they have strong emotional attachment for various forms of support during the emergence phase (Renzulli et al., 2000; Ruef et al., 2003). When the start-up evolves over time, relationships with former unknown parties need to be developed to get access to investors, new information and new clients. This is a challenge for the student entrepreneur. The fact that the students are introduced to other entrepreneurs, mentors and students from other faculties helps them to expand their network (Lockett et al., 2017, Rasmussen et al, 2015). Variation of strong and weak ties in a network also gives significant better performance for start-ups (Baum et al., 2000; Newbert et al.,2013). This variety can improve the social network, so if the network initially consists of mostly strong ties of family and friends, it can be expanded with weak ties in a way that they become strong ties over time and the network consists of a mix of strong ties, weak ties and weak ties becoming strong ties( Newbert et al., 2013). While arguing that there are multiple paths to success, it must be said that there is a likely path to failure when the nascent entrepreneur is unable to diversify his network and sticks to a homogenized network over time. He will not be able to acquire the resources critical to an organization's success (Newbert et al., 2013). When entrepreneurs build their social network, social mechanisms (like: information access, brokerage, status, embeddedness and sanctions) play an important role in the entrepreneurial process of opportunity identification, resource mobilization and gaining legitimacy (Stuart and Sorenson, 2007; Hoang and Antoncic, 2003). For (student) entrepreneurs it is importance to use these mechanisms to expand their network. What can be said of these mechanisms?

\subsection{Information Access}

Research in rural surrounding occupied with specific industries show that strong ties are the most important for businesses to survive and prosper (Jack et al., 2008). According to Jack et al., the multiplexity of ties seems to be decisive for businesses to get hold of the resources needed to develop. This means that entrepreneurs become involved with each other through events that are not directly connected to their businesses, e.g. local committees or non-political service organizations like the Lions club. The exchange of high-quality information becomes the major network function (Jensen, 2002). In these cases an entrepreneur needs to invest time in developing strong ties in the local business community, otherwise his business will fail. In general, strong ties are built upon trust and can be used for the transfer of fine-grained information, tacit knowledge and joint problem Solving (Uzzi, 1996; Rowley et al., 2000). On the other hand weak ties often bring in new knowledge and give the entrepreneur the opportunity to develop into an operational organization (Elfring and Hulsing, 2007; Newbert et all, 2013).

\subsection{Brokerage}

Entrepreneurs can be introduced to new partners by their strong ties (brokerage). For instance the referral of a founder to potential funding sources by a venture advocate is a critical networking behavior for start-ups. It is not unusual for venture capitalists to note that they do not even evaluate unsolicited business plans (Stuart and Sorenson, 2007). Rather, the only plans that receive any attention are those referred by members of their networks. Sometimes these members are university professors. Occasionally, these advocates may provide limited interest-free loans or other seeding to help a venture move from one stage to another (Stuart and Sorenson, 2007). This reliance on referral-based searches has been pointed out in literature already (Vissa \& Bhagavatula, 2012), especially regarding the principals of effectuation and affordable loss (Sarasvathy, 2001). Scholars also argue that social capital itself is a critical conversion factor toward developing entrepreneurial capability and sometimes powerful connections are needed for (student) entrepreneurs to benefit from specific resources (Wakkee, et al., 2017).

\subsection{Status}

A great deal of uncertainty surrounds nascent entrepreneurs, in particular when they do not have a former track record, resource providers find it difficult to assess the quality of the venture or the idea. It has already been proven that founders from entrepreneurially prominent prior employers, who start a new firm, attract more external financing for their ventures (Burton et al., 2002).

By frequently interacting with their surroundings, nascent entrepreneurs can involve their supporters in their activities and build trust about the activities they are developing, this helps resource providers to make decisions about backing 
up start-ups (Hallen \& Eisenhardt, 2012). By conveying the entrepreneur's personal credibility, professional organizing, organizational achievement and the quality of stakeholder relationships, start-ups are able to gain resources more easily (Zott \& Huy, 2007). Personal credibility can be shown by somebody's education and what he or she has achieved until now. Professional organizing is harder to show when a company is in its early stage but when a start-up can show awards and prices won during competitions it also contributes to their credibility. The relation with already established firms or entrepreneurs who are stakeholders is also one of the symbols that can convince other parties to share resource with a student entrepreneur (Zott \&Huy, 2007).

\subsection{Embeddedness and Sanctions}

As already stated in the paragraph on brokerage it can be important to have friends or acquaintances who can introduce you to business partners that can be of interest for you while they possess resources you need. In these cases often personal relations and business relations develop alongside economic exchanges and trust and feelings of obligations toward trading partners develop. As a consequence, transgressing the terms of an embedded economic exchange can become tantamount to cheating a friend (Granovetter, 1985), with the implication that narrow conceptions of self-interest cannot explain conduct in these contexts (Stuart and Sorensen, 2007).

Venture capitalists appear to prefer to invest in fledgling firms they learn of through referrals by close contacts, including entrepreneurs they have previously sponsored, fellow venture capitalists, family members, and other professional contacts (Shane and Stuart, 2002). Because information about actors' conduct in previous transactions diffuses through the connections in a network, actors will know of the past behavior of the other members of the network within their information spheres, and they will have the power to sanction their transaction partners by disseminating negative information about them in the event of malfeasant behavior (Granovetter 1985, Raub and Weesie 1990). As a nascent entrepreneur it could be necessary and beneficial to leverage ties to supporters with whom you have exchanged in the past, but it would be wise to avoid relying on a small number of supporters for the majority of your resources to avoid a kind of dependency on them (Newbert et al., 2013). So there are two sides to the medal of embeddedness entrepreneurs need to be aware of.

Based upon the several mechanisms and processes we developed a conceptual model (fig.1) that accentuates the way the mechanisms of social networking influence the access to new information, clients, capital and other resources. By using these mechanisms the network of the entrepreneur changes. The way an entrepreneur uses these mechanisms is also decisive for the continuance of the company in progress.

\section{Methodology}

The fact that it has become more popular among students to start a business during their bachelor or master study and universities are developing programs to stimulate entrepreneurial competencies (Alsaaty et al.,2014; Harkema \& Schout,2008; Rasmussen et al.,2015) is one of the reasons why we decided to follow this group. The fact that they all had comparable social networks that needed to be developed was another reason. During the academic years 2009-2010 and 2010-2011, we followed 165 companies started during a six-month venture creation program (30 ECTS) in the third or fourth year of the bachelor phase (Table 1). In this paragraph we will picture the context of this research and show the methods we used to answer the research question about the development of the networks of these young entrepreneurs.

Table 1. Number of companies

\begin{tabular}{llll}
\hline Academic year & $\begin{array}{l}\text { Number of companies } \\
\text { started (165) }\end{array}$ & $\begin{array}{l}\text { Still active six months } \\
\text { after the course. (17) }\end{array}$ & December 2013 (7) \\
\hline $1-9-2009-1-2-2010$ & 44 & 7 & 3 \\
$1-2-2010-1-7-2010$ & 32 & 3 & 2 \\
$1-9-2010-1-2-2011$ & 54 & 3 & 1 \\
$1-2-2011-1-7-2011$ & 35 & 4 & 1 \\
\hline
\end{tabular}

During the 20-week venture creation program the bachelor students start searching for a concept they could develop and bring to the market (Opportunity recognition). The first four weeks are spent on market research and building a team that has the right qualities to do the job. After that the start-up team, of one up to four students, registers at the Chamber of Commerce in the Netherlands and works on developing the product or service they have chosen (Resource Mobilization). Every team has a dedicated coach that meets the team every week to talk about the developments. After they developed their concept/product they started selling it and worked on their marketing and publicity (Gaining Legitimacy, building status). During the program workshops were given to the students in which they could develop entrepreneurial skills like sales, marketing and networking. Also classes about legal aspects, finance and human resources were part of the program.

After 20 weeks the students were assessed on their progress and were rewarded (or not) with 30 ECTS for their 
bachelor study of applied sciences. We followed a group of 17 student entrepreneurs that went on with their business after the venture creation program.

The 17 companies that continued after the venture creation program are listed below (table 2).

Table 2. Information about the 17 start-ups followed during this research.

\begin{tabular}{|c|c|c|c|c|}
\hline $\begin{array}{l}\text { Name } \\
\text { company) }\end{array}$ & Sector & $\begin{array}{l}\text { Team composition } \\
(\mathrm{m}=\text { male, } \\
\mathrm{f}=\text { female })\end{array}$ & $\begin{array}{l}\text { Performance } \\
\text { (turnover/employees } \\
\text { 2013) }\end{array}$ & $\begin{array}{l}\text { Status in } \\
\text { December } 2013\end{array}$ \\
\hline Fans (Jan. 2010) & Hospitality-leisure & $1 \mathrm{~m}$ & $0 / 0$ & Stopped \\
\hline Taxi (Jan. 2010) & Hospitality-leisure & $1 \mathrm{~m}$ & $50 \mathrm{k}-100 \mathrm{k} / 3$ & Still active \\
\hline $\begin{array}{l}\text { Rappers } \\
\text { (Sept. 2011) }\end{array}$ & Entertainment-media & $1 \mathrm{~m}$ & $0 \mathrm{k}-5 \mathrm{k} / 0$ & Stopped \\
\hline $\begin{array}{l}\text { Sites } \\
\text { (Sept. 2010) }\end{array}$ & Entertainment-media & $1 \mathrm{~m}$ & $10 \mathrm{k}-50 \mathrm{k} / 0$ & Still active \\
\hline $\begin{array}{l}\text { Massage } \\
\text { (Jan. 2011) }\end{array}$ & Hospitality-leisure & $2 \mathrm{~m}$ & $0 \mathrm{k}-5 \mathrm{k} / 0$ & Stopped \\
\hline Claim (Jan. 2011) & Financial services & $3 \mathrm{~m}$ & $250 \mathrm{k}-500 \mathrm{k} / 10$ & Still active \\
\hline $\begin{array}{l}\text { Presentation } \\
\text { (Sept. 2011) }\end{array}$ & Entertainment-media & $2 \mathrm{~m}$ & $250 \mathrm{k}-500 \mathrm{k} / 12$ & Still active \\
\hline Bags (Sept. 2011) & Retail-consumer & $2 \mathrm{~m} \mathrm{1f}$ & $0 \mathrm{k}-5 \mathrm{k} / 0$ & Stopped \\
\hline $\begin{array}{l}\text { Furniture } \\
\text { (Jan. 2010) }\end{array}$ & Retail-consumer & $1 \mathrm{~m}$ & $0 \mathrm{k}-5 \mathrm{k} / 0$ & Stopped \\
\hline $\begin{array}{l}\text { Lenses } \\
\text { (Jan. 2010) }\end{array}$ & Retail-consumer & $1 \mathrm{~m}$ & $10 \mathrm{k}-50 \mathrm{k} / 0$ & Still active \\
\hline $\begin{array}{l}\text { Lingerie } \\
(\text { Jan. 2010) }\end{array}$ & Retail-consumer & $1 \mathrm{f}$ & $100 \mathrm{k}-250 \mathrm{k} / 2$ & Still active \\
\hline $\begin{array}{l}\text { Catering } \\
(\text { Jan. 2010) }\end{array}$ & Hospitality-leisure & $1 \mathrm{~m}$ & $0 / 0$ & Stopped \\
\hline Sales (Sept.2010) & Financial services & $2 \mathrm{~m}$ & $0 / 0$ & Stopped \\
\hline $\begin{array}{l}\text { Music } \\
\text { (Jan. 2011) }\end{array}$ & Entertainment-media & $1 \mathrm{~m}$ & $0 \mathrm{k}-5 \mathrm{k} / 0$ & Stopped \\
\hline Sushi (Sept. 2011) & Hospitality-leisure & $2 \mathrm{f}$ & $0 / 0$ & Stopped \\
\hline $\begin{array}{l}\text { Working (Sept. } \\
2010)\end{array}$ & Financial services & $1 \mathrm{~m}$ & $0 / 0$ & Stopped \\
\hline $\begin{array}{l}\text { Appbuilder } \\
\text { (Jan. 2010) }\end{array}$ & Entertainment-media & $3 \mathrm{~m}$ & $100 \mathrm{k}-250 \mathrm{k} / 5$ & Still active \\
\hline
\end{tabular}

Within the period of three years we interviewed the start-ups, 10 out of the 17 start-ups quit their business within three years. In the period we interviewed the 10 start-ups that quit within a period of three years their network did not develop or even diminished (Table 3). They used their network of families and friends, but did not reach out to other contacts, or were not able to consolidate these contacts.

\subsection{Interviews}

The qualitative nature of the research question prompted to conduct a multiple case deductive study (Eisenhard, 1989) on several companies started by bachelor students. At the end of the venture creation program the owners of all companies that followed the program ( 165 over a period of two years) were interviewed about the results they produced and the people and companies that were involved in bringing the start-up to the stage that it was in at the time. The interviews were conducted, following a predesigned topic list, about their turnover, sales, costs and profit, but also about being registered at the Chamber of Commerce, patenting, financing, marketing activities, employees and the continuation of the business (according to model of Davidsson and Honig, 2003). The interviews were immediately processed in an Excel sheet and a Google docs form. The 165 interviews were held by the author and a student assistant. The interviews lasted between 30 and 45 minutes. Out of these data we could draw conclusions about the development of the social network of the student entrepreneurs during the venture creation program. While we liked to see the development of the social network over a longer period of time we followed the student entrepreneurs of the 17 companies that went on after the venture creation program.

We conducted follow-up interviews on these 17 student companies. The same predesigned topic list was used and the data were processed on the spot. We asked also questions about the development of their network. A couple of the interviews were recorded. These interviews lasted between 30 to 45 minutes. The followed student start-ups were service-oriented businesses. Data were also collected by checking, information from their sites, press releases, and 
publications in the media. We also attended meetings were student entrepreneurs presented their company to win awards. We looked at the networking mechanisms that were involved in the entrepreneurial process the students activated over the years. This meant that we analyzed the interviews by looking into the role of information access, brokerage, status, embeddedness and sanctions as part of the process of opportunity recognition, finding resources and gaining legitimacy (Elfring and Hulsink, 2003, Stuart and Sorenson, 2007), to get a better understanding about the way student entrepreneurs developed their social network over time. The interviews were interpreted and appropriate quotes of the student were matched with the specific mechanism they related to and the process the company was in at that time (opportunity recognition, finding resources or gaining legitimacy), to support our findings.

The start-ups that continued after the venture creation program, were interviewed once a year till January 2014 (in 10 of the cases interviews were stopped at an earlier stage, because the student entrepreneurs quit their business). At this time (January 2014) only 7 of the originally followed start-ups were still active.

\section{Analysis of the Cases}

As shown in table 3 and figure 3 and 4, the network of almost all the start-ups that were still active after a period of three years grew. The size of the network of weak ties grew most for the most successful start-ups, Claim, Presentation and Lingerie. They also were the only three start-ups that developed internationally. The other start-ups operated only locally and generated only an income for the owners (except Appbuilder, but in this case the network development was hindered by the fact that two of the owners left the company, so the remaining owner had a major setback). The size of the social network of the 10 student companies that quit within a period of three years didn't grow and even diminished in most of the cases. Reasons that these student entrepreneurs quit were that they weren't able to reach out to external relations for investments, didn't manage to get free publicity by winning prices or couldn't connect to new clients while being too busy with their operations. Two of the student entrepreneurs quit their company to start working for their launching customer.

Table 3. Growth in ties (first year, compared to second year)

\begin{tabular}{l|c|c|c}
\hline Company & $\begin{array}{l}\text { Network size } \\
\text { end of year } \\
\text { one }\end{array}$ & $\begin{array}{l}\text { Network size end } \\
\text { of year two }\end{array}$ & Percentage growth \\
\hline Fans & 6 & 8 & $33 \%$ \\
\hline Taxi & 8 & 10 & $43 \%$ \\
\hline Rappers & 8 & 8 & $0 \%$ \\
\hline Sites & 3 & 10 & $25 \%$ \\
\hline Massage & 18 & 3 & $0 \%$ \\
\hline Claim & 9 & 24 & $43 \%$ \\
\hline Presentation & 11 & 13 & $-27 \%$ \\
\hline Bags & 3 & 8 & $0 \%$ \\
\hline Furniture & 12 & 3 & $-17 \%$ \\
\hline Lenses & 7 & 10 & $186 \%$ \\
\hline Lingerie & 8 & 20 & $-25 \%$ \\
\hline Catering & 5 & 6 & $-40 \%$ \\
\hline Sales & 8 & 3 & $-50 \%$ \\
\hline Music & 11 & 4 & $-55 \%$ \\
\hline Sushi & 5 & 5 & $-40 \%$ \\
\hline Working & 7 & 3 & $71 \%$ \\
\hline Appbuilder & 12 & 5 \\
\hline
\end{tabular}

In figure 2 and 3 the development of the social networks weak - and strong ties is shown of the companies that were part of this research, showing their development using graphics like used by Newbert et al.,2013. 


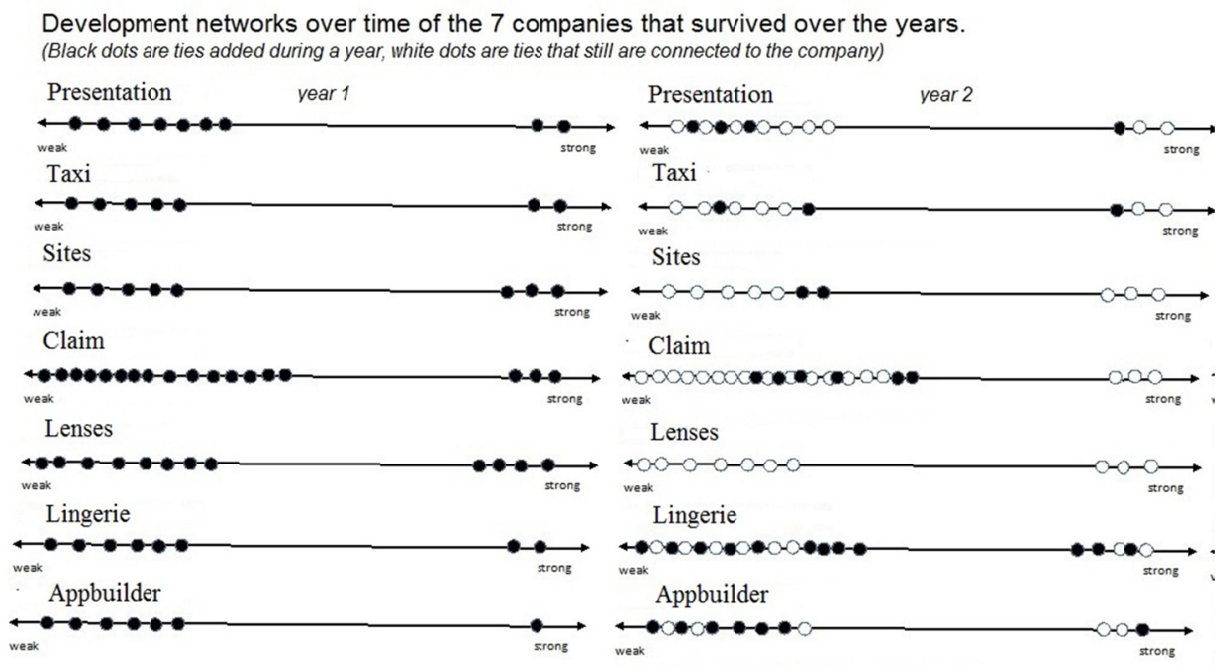

Figure 2. The development of the social network of the 7 companies that were still active (January 2014)

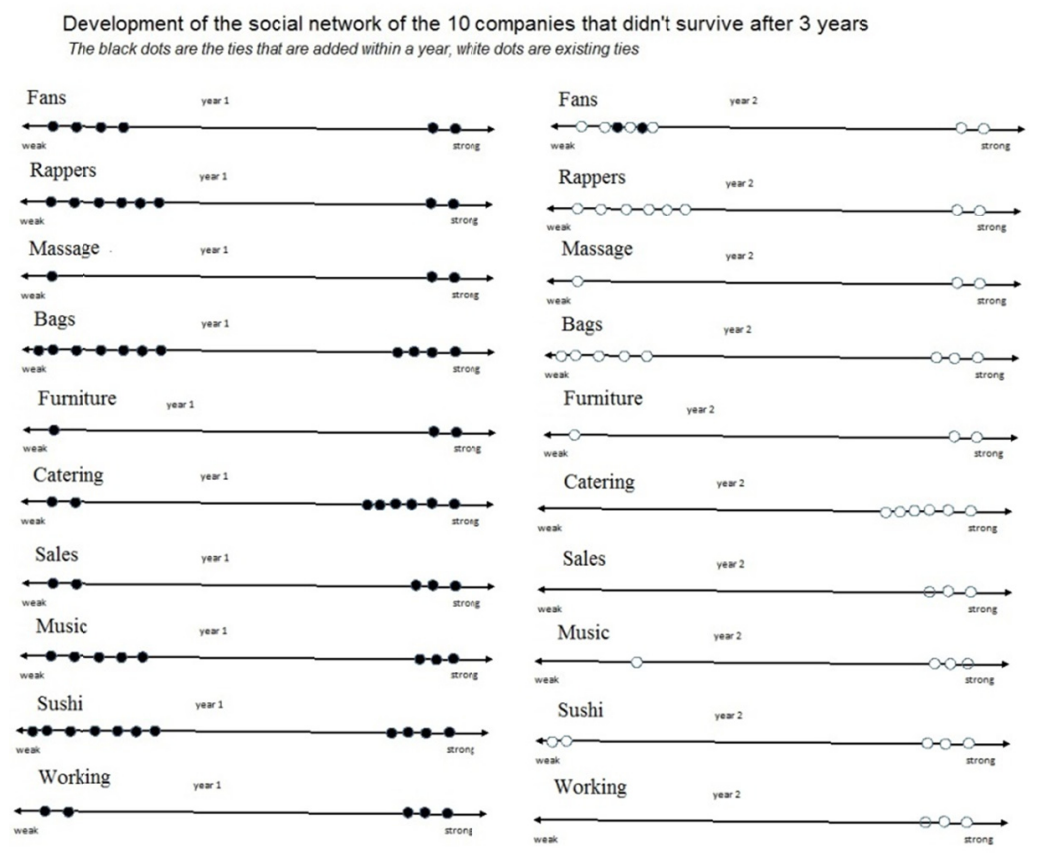

Figure 3. The development of the network of the 10 companies that quit their business within three years after the venture creation program (January 2014).

\subsection{Strong Versus Weak Ties}

Most students depended on their strong ties (family and friends) to get their first resources. This is in line with the findings of Zimmermann et al. (2002) who concluded that due to a limited track record of the entrepreneur and his venture potential customers, suppliers and other stakeholders in the environment are reluctant to commit resources to a new business start-up. This also has to do with the social mechanism of status.

The 17 cases I describe in this article also started with strong ties in the first period of their start-up, but after a short period of time they started to connect to former unknown people from businesses they didn't now at first.

7 student entrepreneurs out of the 17 cases were successful in making these connections. The other 10 students were not able to develop their network skills in this period of time and therefore could not connect to the outer world. We would like to state that the students connected to the 10 companies that were out of business within three years, were not able to connect to business contacts needed for the survival of their company. The student start-up that used their family for, working within their catering start-up were able to provide their first services, but because they did not expand their network, there were no orders for new events and the start-up failed (Catering). "I had to do the catering 
for relations connected to my family, but after these orders, I wasn't able to bring in new ones."

The entrepreneur of Lingerie used her family network to get a loan of $€ 50 \mathrm{k}$ to invest in her first stock and for financing the website. She took a big risk in doing so, but while she was fully committed to her start-up and promoted her company well, she managed to gain legitimacy within her first year and was able to bind international suppliers to her. She could make appointments about her stock and was able to order directly from her suppliers, bringing her cost down to an acceptable level. "The support of my family helped me to overcome the moments of doubt I had at the beginning of my adventure."

The network of Claim became heterogeneous by connecting with weak ties at the moment needed, e.g. these students had no contacts in the travel industry or in the legal world. By making contacts through their student association, in no time they developed the right connections. Once they had a contact with a big network in the travel industry, they considered hiring this person to help them, but in the end they could do without his help and grew their network fast enough to make progress. Quote of the founder: "I asked myself, do we need this person to get in contact with our target group or can we reach them ourselves?"

As I was told by these student entrepreneurs, their network started to work for them over time. The more their business grew, the more interesting people popped up in their network. They had to learn to distinguish in which weak ties they needed to invest their time and which ones they had to let go.

Proposition 1a: Student entrepreneurs who started to operate internationally with their start-up were more attractive to invest in by weak ties than local operating Student entrepreneurs. This helped in the period of resource mobilization and gaining legitimacy to reach out to new relations.

Proposition 1b: Investing time in creating free publicity, participating in business competitions and visiting industry events helped student entrepreneurs to expand their network. These activities mostly helped by gaining legitimacy.

\subsection{Brokerage and Information Access}

The connection with lawyers and accountants gave Claim the opportunity to connect with the right resources (the mechanism of information access in the period of opportunity identification). This is in line with the research of Alice de Koning (2003), who emphasized that most successful entrepreneurs obtained their information by contacting people and talking about opportunities. Especially lawyers and accountants were professionals you could share your thoughts with, without having to consider that they would steal the idea for themselves, according to the entrepreneurs interviewed by Alice de Koning (2003). Claim also often used an online network of experts "After a while consultants started asking money for the time we spent with them, so in the end our impartiality diminished and we became more critical about the people we spent time with, although the goodwill factor remained an important asset" (quote entrepreneur claim).

The network of Taxi developed by word of mouth. The founder said: "If the CEO that I was driving around felt happy and was satisfied with the service I delivered, he often recommended me to other CEOs in his network and so my business grew slowly but steadily" (the mechanism of brokerage while gaining legitimacy and mobilizing resources).

The network of Presentation became heterogeneous by doing assignments for Ogilvy in exchange for the free rent of a part of the office of Ogilvy. This also was a result of being an intern at Ogilvy's in the first place. In this way they made their first contact in the industry and in no time they were given assignments by Coca Cola, Vodafone, Philips and other multinationals. Quote founder: "One of the CEOs of Ogilvy specially liked our work and introduced us to several companies in his network, this helped us a lot" (the mechanism of brokerage for resource mobilization and gaining legitimacy). This kind of intelligent altruism and bartering between Presentation and Ogilvy is noticed in the literature as a part of an effectual networking strategy in which entrepreneurs act in a way that benefits others as well as themselves (Sarasvathy \& Dew, 2008).

All the student entrepreneurs (in the group of 7 start-ups that survived) were not afraid to ask for help. While they were young and inexperienced, they experienced a lot of goodwill from the people they approached. This also is in line with the conclusions of Saxton et al. (2016) who suggested that the venture advocate who possesses the necessary means to assist a founder of a new company will do so, while this increases his status within the start-up community.

Proposition 2a: Student entrepreneurs get access to new information when they are not afraid to ask for help and use the goodwill factor the outside world has towards them. This helps in the period of opportunity identification and resource mobilization.

Proposition 2b: Student entrepreneurs use brokerage by making their clients ambassadors for their company while gaining legitimacy and mobilizing resources.

Proposition 2c: Student entrepreneurs who share their information with e.g. lawyers and accountants are able to adjust 
their proposition for the better. They use their network for opportunity recognition.

\subsection{Status}

The student entrepreneurs that were unable to establish a good communication with their surroundings do not exist anymore.

Claim, Lingerie and Presentation were able to promote their start-up by winning awards and getting free publicity in papers and online magazines (status-enhancing). They even got attention on national television. Claim benefitted from the attention by establishing a relationship with the municipality of Amsterdam and companies like Ernst \& Young. Presentation won awards by making the best Prezi presentations in the world (according to Prezi) and becoming a preferred Prezi supplier. Clients who were satisfied about their service became in some occasions fans and introduced Presentation to their relations. The network of Lingerie became heterogeneous by contacting different players in the lingerie business: photographers, stylists, celebrities, etcetera. The exclusivity and quality of her products drew different resources. Quote founder Lingerie: "The fact that Victoria Koblenko wears my lingerie and promotes it publicly helped me a lot to reach out to the rich and famous".

The entrepreneur of Appbuilder also appeared frequently in the local news, he won a local award for most innovative entrepreneur and took care of a lot of free publicity. The student entrepreneurs of Sites, Lenses and Taxi did not reach out to the press often and this is one of the reasons their network developed slowly. These three companies didn't hire employees. The variety of symbolic actions (like winning awards) enabled the student entrepreneurs to get recognition from the outside world and to build on their status.

Proposition 3: Student entrepreneurs work on the status of their start-up by connecting to well-known parties by making use of a variety of symbolic actions, like winning rewards. These activities help them in the process of gaining legitimacy.

\subsection{Embeddedness}

The group of 10 student entrepreneurs that did not work on extending their network to different suppliers or customers were not able to transform their start-ups into operational organizations. These students were so embedded in their network that for a large part their revenue became to depend on one or two clients.

The student entrepreneurs of Massage depended on the university as their client and had to give up after the university did not extend their contract. They were too busy with their operations (giving massages to employees) that they forgot to reach out to new clients. The student start-up Solt worked for one client who they reached through the network of the university and this became so serious that the student entrepreneurs decided to become employees of their client. The student entrepreneurs of Appbuilder were depending on one big client, who offered them to become his employees. This meant that two of three nascent entrepreneurs quit their business and one of them choose to go on alone.

The owners of the other companies were also embedded in their network but they benefitted from this embeddedness. Presentation was doing a lot of work in the slipstream of Ogilvy, but they were able to expand their network by making a couple of their clients ambassador and by doing so connected to a new client base outside of Ogilvy's network . They also benefited from multiplex relationships by, for example, getting involved in projects of the municipality of Amsterdam so that they could contact potentially interesting stakeholders.

In the case of resource mobilization the owner of Lingerie lost a lot of money by forgetting to do a good background research on the party that was responsible for developing her first website. She trusted their professionality and skills without doing a thorough background search. In the end this meant she had to do business with another party that could do the job. "I learned by the hard way to not only trust the people you depend on by looking at their blue eyes".

For resource mobilization the owner of Lingerie also leaned heavily on investments of her family. When her company became more successful she was able to attract credit from her suppliers in a way that she could directly order from their stock and did not have a big stock position of her own. Presentation, Taxi, Appbuilder and Claim were able to invest in the development of their company with their own means. Their employees could be payed from their own means. The profit they made was directly invested in their company so that they did not become dependent on a bank or an investor. Sites and Lenses stayed so small and only had to take care of themselves, so no investments were needed from external parties.

Proposition 4a: Student entrepreneurs embedded in the network of the university or relying on the university as their first customer, can get caught in their operations and forget to make time for networking. This can make them vulnerable in the stage of resource mobilization, and even mean the end of their business.

Proposition 4b: Student entrepreneurs, that were able to recruit ambassadors for their service were able to gain a bigger market share over time, this made them able to earn enough money to invest in their company from their own gained 
resource and made them independent of investors or banks.

\subsection{Sanctions}

During the period of this resource I could only find one company that had to deal with sanctions during their development, this was claim while expanding their business to Germany. The first year of their operations they had a lot of challenges with dealing with several laws within Germany. They were sued for not acting within the German law and had to withdraw them for a while from the German market in order to get their operation straight. A second attempt was successful with the help of local connections.

\section{Conclusions and Future Research}

\subsection{Conclusions}

In this paper we developed a conceptual model based on earlier research (figure 1) in which the relationship between mechanisms of social networking and the entrepreneurial processes of getting access to new information, mobilizing resources and gaining legitimacy are distinguished. Using these mechanisms while going through the several phases will develop the entrepreneurial network. This paper addresses the question how student entrepreneurs develop their network using these mechanisms going through the specified phases while creating their company.

Based on the results of the case studies we conclude that the ongoing development of the social network is of crucial importance for the survival of the start-up. Once you stop with developing your network, your start-up is bound to disappear. In 10 of the 17 cases we followed in this research one of the reasons the student entrepreneur was unable to make his start-up work had to do with the fact that the student entrepreneur was not able to connect to new ties (clients, investors, suppliers, etc.) in order to get the necessary resources for his company to develop. The student entrepreneurs that developed a scalable, internationally oriented business were the most successful in attracting resources for their start-up.

Secondly it gives an insight in the two sides of the medal of being embedded in a social network. On one side embeddedness can give access to new resources and information, but on the other side it can make you blind for the further development of your company and make you depend on your first client. In the cases of the student entrepreneurs we found that this was of crucial importance for the development of the start-up. Being too much involved on the operational side of your business, without developing new network ties can make you depending on one important client and can mean the end of your business when you lose this client. In the case of the student start-up Appbuilder the third owner showed that losing your most important client does not always mean the end for a company. Strong commitment in combination with a good service/product can help you to survive with the help of others.

Our research also reinforces the existing insight about the importance of developing a heterogeneous social network consisting of strong and weak ties in order to establish a profitable organization (Newbert et all, 2013; Elfring \& Hulsink, 2003; Shane \&Cable, 2002).

This research shows the important role of the university in this process, in many cases being a first customer or introducing student entrepreneurs to networks otherwise out of reach for them. This meddling has two sides, the motivated student entrepreneur will use this help as a stepping stone to new experiences but the student entrepreneur with little ambition and the inability to reach out to the outside world makes this the endpoint of his experience and the company stops at the moment the university withdraws.

\subsection{Suggestions for Future Research}

As their network grows and more parties become interested in what they are doing, the student entrepreneurs also need to develop a radar for parties that just want to benefit from their success and have little or nothing to offer. In this process the importance of shared values is being introduced in the choice for partners that are interesting or not. Because this process just started to appear at the end of the period we were monitoring the student entrepreneurs, we think it is interesting to find out how this ranking process works and what other mechanisms are involved. This also might be something worthy for future research.

Also the student entrepreneurs learned how important it is to check the credibility of parties you are going to work closely to and who can damage your reputation or influence important processes you depend on. Often this process is learned the hard way and the student entrepreneur has to build up a new relation with another party and can lose a lot of valuable data. For educators or coaches working with young entrepreneurs this might be something to refer to and also shows the importance of a thorough background checking process. How to proceed exactly in these cases and what the best steps to be taken should be is something that could be of interest for further research.

A last suggestion for further research is based upon the question of Stuart and Sorenson (2007): If networks do confer competitive advantages in entrepreneurial settings, do all actors enjoy equal access in the competition for 
relationship-based resources, or do ascriptive characteristics (like being part of the population of students) affect an actor's ability to acquire a network-based advantage or disadvantage? It seems that the goodwill factor plays an important role in the case of student entrepreneurs, but to find out if this really distinguishes them from non-student entrepreneurs needs to be investigated in more detail.

\section{Acknowledgements}

I am grateful to all the students that were so kind to work with me on my research and without whom I would not have been able to share these thoughts with you. So thank you all!

\section{Reference}

Alsaaty, F. M., David, A., \& Ella, C. (2014). Business students' interests in entrepreneurship and social entrepreneurship at a historically black institution. Journal of Small Business and Entrepreneurship Development, 2(1), 1-30.

Baum, J. A. C., Tony, C., \& Brian, S. S. (2000). Don't go it alone: Alliance network composition and start-ups' performance in Canadian biotechnology. Strategic management journal, 21(3), 267-294. https://doi.org/10.1002/(SICI)1097-0266(200003)21:3<267::AID-SMJ89>3.0.CO;2-8

Bruderl, J., \& Preisendorfer, P. (1998). Network support and the success of newly founded businesses. Small Business Economics, 10, 213-225. https://doi.org/10.1023/A:1007997102930

Burt, R. S. (1997). The contingent value of social capital. Administrative science quarterly, 339-365. https://doi.org/10.2307/2393923

Burton, M. D., Sørensen, J. B., \& Beckman, C. M. (2002). Coming from good stock: Career histories and new venture formation. In Social structure and organizations revisited, 229-262. Emerald Group Publishing Limited. https://doi.org/10.1016/S0733-558X(02)19007-0

Davidsson, P., \& Honig, B. (2003). The role of social and human capital among nascent entrepreneurs. Journal of Business Venturing, 18, 301-331. https://doi.org/10.1016/S0883-9026(02)00097-6

De Koning, A. (2003). Opportunity development: A socio-cognitive perspective. Advances in entrepreneurship, firm emergence and growth, 6, 265-314. https://doi.org/10.1016/S1074-7540(03)06009-4

Eisenhardt, K. M. (1989). Building theories from case study research. Academy of management review, 14(4), 532-550.

Elfring, T., \& Hulsink, W. (2003). Networks in entrepreneurship: The case of high-technology firms. Small Business Economics, 21, 409-422. https://doi.org/10.1023/A:1026180418357

Elfring, T., \& Hulsink, W. (2007). Networking by entrepreneurs: Patterns of tie-formation in emerging organizations. Organization Studies, 28, 1849-1872. https://doi.org/10.1177/0170840607078719

Engel, Y., Kaandorp, M., \& Elfring, T. (2017). Toward a dynamic process model of entrepreneurial networking under uncertainty. Journal of Business Venturing, 32(1), 35-51. https://doi.org/10.1016/j.jbusvent.2016.10.001

Granovetter, M. (1985). Economic action and social structure: The problem of embeddedness. American journal of sociology, 91(3), 481-510. https://doi.org/10.1086/228311

Hallen, B. L., \& Eisenhardt, K. M. (2012). Catalyzing strategies and efficient tie formation: how entrepreneurial firms obtain investment ties. Academy of Management Journal, 55(1), 35-70. https://doi.org/10.5465/amj.2009.0620

Harkema, S. J., \& Schout, H. (2008). Incorporating student-centred learning in innovation and entrepreneurship education. European Journal of Education, 43(4), 513-526. https://doi.org/10.1111/j.1465-3435.2008.00372.x

Hite, J. M., \& Hesterly, W. S. (2001). The evolution of firm networks: From emergence to early growth of the firm. Strategic management journal, 22(3), 275-286. https://doi.org/10.1002/smj.156

Hoang, H., \& Antoncic, B. (2003). Network-based research in entrepreneurship: A critical review. Journal of business venturing, 18(2), 165-187. https://doi.org/10.1016/S0883-9026(02)00081-2

Hulsink, W., \& Koek, D. (2014). The young, the fast and the furious: a study about the triggers and impediments of youth entrepreneurship. International Journal of Entrepreneurship and Innovation Management, 18(2-3), 182-209. https://doi.org/10.1504/IJEIM.2014.062876

Jack, S., Dodd, S. D., \& Anderson, A. R. (2008). Change and the development of entrepreneurial networks over time: a processual perspective. Entrepreneurship and Regional Development, 20(2), 125-159. https://doi.org/10.1080/08985620701645027

Lackéus, M., \& Williams, M. K. (2015). Venture creation programs: bridging entrepreneurship education and technology transfer. Education+ Training, 57(1), 48-73. https://doi.org/10.1108/ET-02-2013-0013 
Lamine, W., Jack, S., Fayolle, A., \& Chabaud, D. (2015). One step beyond? Towards a process view of social networks in entrepreneurship.

Lans, T., Blok, V., \& Gulikers, J. (2015). Show me your network and I'll tell you who you are: social competence and social capital of early-stage entrepreneurs. Entrepreneurship \& Regional Development, 27(7-8), 458-473. https://doi.org/10.1080/08985626.2015.1070537

Lee, R., \& Jones, O. (2008). Networks, communication and learning during business start-up: the creation of cognitive social capital. International Small Business Journal, 26(5), 559-594. https://doi.org/10.1177/0266242608094030

Lockett, N., Quesada, P. C., Williams, M. K., Padilla, M. A., \& Jack, S. (2017). 'Lost in space' The role of social networking in university-based entrepreneurial learning. Industry and Higher Education, 31(2), 67-80. https://doi.org/10.1177/0950422217693962

Newbert, S. L., Tornikoski, E. T., \& Quigley, N. R. (2013). Exploring the evolution of supporter networks in the creation of new organizations. Journal of Business Venturing, 28(2), 281-298. https://doi.org/10.1016/j.jbusvent.2012.09.003

Podolny, J. M., \& Baron, J. N. (1997). Resources and relationships: Social networks and mobility in the workplace. American sociological review, 673-693. https://doi.org/10.2307/2657354

Rasmussen, E., Mosey, S., \& Wright, M. (2015). The transformation of network ties to develop entrepreneurial competencies for university spin-offs. Entrepreneurship \& Regional Development, 27(7-8), 430-457. https://doi.org/10.1080/08985626.2015.1070536

Raub, W., \& Weesie, J. (1990). Reputation and efficiency in social interactions: An example of network effects. American Journal of Sociology, 96(3), 626-654. https://doi.org/10.1086/229574

Renzulli, L. A., Aldrich, H., \& Moody, J. (2000). Family matters: Gender, networks, and entrepreneurial outcomes. Social forces, 79(2), 523-546. https://doi.org/10.1093/sf/79.2.523

Rowley, T., Behrens, D., \& Krackhardt, D. (2000). Redundant governance structures: An analysis of structural and relational embeddedness in the steel and semiconductor industries. Strategic management journal, 369-386. https://doi.org/10.1002/(SICI)1097-0266(200003)21:3<369::AID-SMJ93>3.0.CO;2-M

Ruef, M., Aldrich, H. E., \& Carter, N. M. (2003). The structure of founding teams: Homophily, strong ties, and isolation among US entrepreneurs. American sociological review, 195-222. https://doi.org/10.2307/1519766

Sarasvathy, S. D. (2001). Causation and effectuation: Toward a theoretical shift from economic inevitability to entrepreneurial contingency. Academy of management Review, 26(2), 243-263.

Sarasvathy, S., \& Dew, N. (2008). Effectuation and Over-Trust: Debating Goel and Karri. Entrepreneurship Theory and Practice, 32(4), 727-737. https://doi.org/10.1111/j.1540-6520.2008.00250.x

Saxton, T., Wesley, C. L., \& Saxton, M. K. (2016). Venture Advocate Behaviors and the Emerging Enterprise. Strategic Entrepreneurship Journal, 10(1), 107-125. https://doi.org/10.1002/sej.1212

Schutjens, V., \& Stam, E. (2003). The evolution and nature of young firm networks: a longitudinal perspective. Small Business Economics, 21(2), 115-134. https://doi.org/10.1023/A:1025093611364

Seibert, S. E., Kraimer, M. L., \& Liden, R. C. (2001). A social capital theory of career success. Academy of management journal, 44(2), 219-237. https://doi.org/10.2307/3069452

Shane, S., \& Cable, D. (2002). Network ties, reputation, and the financing of new ventures. Management Science, 48(3), 364-381. https://doi.org/10.1287/mnsc.48.3.364.7731

Shane, S., \& Stuart, T. (2002). Organizational endowments and the performance of university start-ups. Management science, 48(1), 154-170. https://doi.org/10.1287/mnsc.48.1.154.14280

Stam, W., Arzlanian, S., \& Elfring, T. (2014). Social capital of entrepreneurs and small firm performance: A meta-analysis of contextual and methodological moderators. Journal of Business Venturing, 29(1), 152-173. https://doi.org/10.1016/j.jbusvent.2013.01.002

Stuart, T. E., \& Sorenson, O. (2007). Strategic networks and entrepreneurial ventures. Strategic Entrepreneurship Journal, 1(3-4), 211-227. https://doi.org/10.1002/sej.18

Uzzi, B. (1996). The sources and consequences of embeddedness for the economic performance of organizations: The network effect. American sociological review, 674-698. https://doi.org/10.2307/2096399

Vissa, B. (2012). Agency in action: Entrepreneurs' networking style and initiation of economic exchange. Organization Science, 23(2), 492-510. https://doi.org/10.1287/orsc.1100.0567 
Vissa, B., \& Bhagavatula, S. (2012). The causes and consequences of churn in entrepreneurs' personal networks. Strategic Entrepreneurship Journal, 6(3), 273-289. https://doi.org/10.1002/sej.1138

Wakkee, I., Hoestenberghe, K., \& Mwasalwiba, E. (2017). Capability, social capital and opportunity-driven graduate entrepreneurship in Tanzania. Journal of Small Business and Enterprise Development. https://doi.org/10.1108/JSBED-02-2017-0053

Witt, P. (2004). Entrepreneurs' networks and the success of start-ups. Entrepreneurship \& Regional Development, 16(5), 391-412. https://doi.org/10.1080/0898562042000188423

Zimmerman, M. A., \& Zeitz, G. J. (2002). Beyond survival: Achieving new venture growth by building legitimacy. Academy of Management Review, 27, 414-431.

Zott, C., \& Huy, Q. N. (2007). How entrepreneurs use symbolic management to acquire resources. Administrative Science Quarterly, 52(1), 70-105. https://doi.org/10.2189/asqu.52.1.70

\section{Copyrights}

Copyright for this article is retained by the author(s), with first publication rights granted to the journal.

This is an open-access article distributed under the terms and conditions of the Creative Commons Attribution license which permits unrestricted use, distribution, and reproduction in any medium, provided the original work is properly cited. 